\title{
Information asymmetries in EU VAT
}

Citation for published version (APA):

Nellen, F. J. G. (2017). Information asymmetries in EU VAT. [Doctoral Thesis, Maastricht University]. Datawyse / Universitaire Pers Maastricht. https://doi.org/10.26481/dis.20170330fn

Document status and date:

Published: 01/01/2017

DOI:

10.26481/dis.20170330fn

Document Version:

Publisher's PDF, also known as Version of record

\section{Please check the document version of this publication:}

- A submitted manuscript is the version of the article upon submission and before peer-review. There can be important differences between the submitted version and the official published version of record.

People interested in the research are advised to contact the author for the final version of the publication, or visit the DOI to the publisher's website.

- The final author version and the galley proof are versions of the publication after peer review.

- The final published version features the final layout of the paper including the volume, issue and page numbers.

Link to publication

\footnotetext{
General rights rights.

- You may freely distribute the URL identifying the publication in the public portal. please follow below link for the End User Agreement:

www.umlib.nl/taverne-license

Take down policy

If you believe that this document breaches copyright please contact us at:

repository@maastrichtuniversity.nl

providing details and we will investigate your claim.
}

Copyright and moral rights for the publications made accessible in the public portal are retained by the authors and/or other copyright owners and it is a condition of accessing publications that users recognise and abide by the legal requirements associated with these

- Users may download and print one copy of any publication from the public portal for the purpose of private study or research.

- You may not further distribute the material or use it for any profit-making activity or commercial gain

If the publication is distributed under the terms of Article $25 \mathrm{fa}$ of the Dutch Copyright Act, indicated by the "Taverne" license above, 


\section{chaperer 19}

\section{Summary and Conclusions}

\subsection{INTRODUCTION}

This thesis has studied the phenomenon of tax information asymmetries between the taxable person and his transaction counterpart in the context of EU VAT. This final part of the thesis (Part VI) provides an overview of the conclusions of the thesis, additionally producing a summary which recaptures the primary research findings.

The following section (19.2) provides a concise overview of the most important conclusions of the research. Subsequently, sections 19.3 to 19.6 contain the conclusions for each of the four research questions of the thesis. Finally, Chapter 20 translates the academic outcomes of the thesis into concrete reflections, as well as recommendations for taxable persons, the (EU) legislator, and academia. 
Figure 19.1.A. Research structure overview

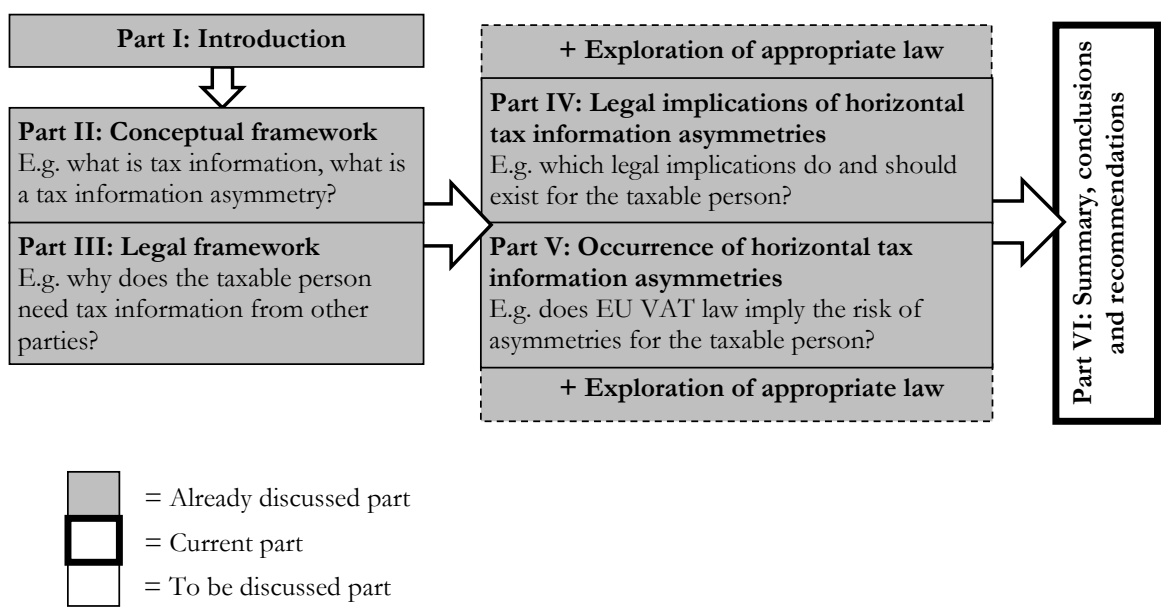

\subsection{CENTRAL CONCLUSIONS}

The first central conclusion of the thesis is that horizontal tax information asymmetries between the taxable person and his transaction counterpart are a real possibility with regard to positive EU VAT law. For the purposes of taxation, the taxable person depends to a considerable extent on tax information held by others. At the same time, EU VAT law provides him with no adequate instruments, legal or other, to resolve asymmetries or prevent their materialization. Instead, the taxable person is expected to arrange the procurement of external tax information on the basis of his commercial interaction with his transaction counterparts. To obtain access to the tax information, he may have to rely on his bargaining power and the willingness of these transaction counterparts to cooperate. In that regard, the procurement of tax information can by no means be regarded as an infallible process, as it may be frustrated by commercial conflicts, limitations of confidentiality or privacy, and other interferences. Additionally, in case the disclosure of tax information indeed becomes a commercial bargaining item, it may influence other aspects of the respective transaction (e.g. price or delivery terms). Such an outcome implies a violation of neutrality.

The second central conclusion of the thesis is that in the field of (EU) VAT, the actual materialization of a horizontal tax information asymmetry has a disruptive impact on taxation. An asymmetry may give rise to adversities such as double taxation, non-taxation, accumulation of VAT, differential VAT treatments of similar transactions, adverse selection, and other market inefficiencies. In addition, an 
asymmetry may imply that the taxable person is confronted with legal implications (i.e. material VAT corrections, sanctions) which cannot be justified when taking into account the legal principles inherent in the system of EU VAT. Further to this, the imposition of material VAT corrections and sanctions should ideally be based on a balanced weighing of the legal principles against the backdrop of the factual circumstances at hand. Following the principle of fiscal neutrality, an asymmetry should not have legal implications (i.e. material VAT corrections) for the taxable person in case their imposition leads to the application of VAT contrary to the objective characteristics of the underlying transaction, or in case the taxable person is unable to transfer the burden of VAT to the final consumer. With regard to the principle of legitimate expectations (as the corollary of the principle of legal certainty), an asymmetry should not lead to material VAT corrections for the taxable person in case that person, while being subject to the asymmetry, has relied on legitimate expectations in the course of taxation. Additionally, the principle of legal simplicity and effectiveness opposes material VAT corrections when the asymmetries that have caused their imposition are effectively the consequence of obligations which have, to an unreasonable extent, complicated the application of VAT by the taxable person. Finally, the principle of proportionality opposes the imposition of material VAT corrections and sanctions on the taxable person in case he has acted in good faith and has done everything which could reasonably be expected from him to resolve the asymmetry or prevent its materialization.

The third central conclusion of the thesis is that both the disruptive effect of asymmetries and the tax information dependencies of the taxable person call for a reconsideration of the tax information position of the taxable person in EU VAT. Following current positive EU VAT law, tax information obligations (i.e. administration and disclosure requirements) are almost exclusively imposed on the taxable person who is held to apply VAT as the subject of taxation. If this one-sided reliance on the taxable person is to be maintained, he should ideally not be expected to procure external tax information to which he has no efficient access. In this regard, (rebuttable) presumptions may be employed to alleviate the tax information position of the taxable person. Another option to counter the materialization of asymmetries is to revise the current distribution of tax information obligations between the taxable person, his transaction counterparts, and the national public authorities. If we accept that tax information is indeed indispensable for taxation, it should ideally be procured and administrated by the party who, in all reasonability, has the most efficient access to it.

The above primary conclusions are connected to a range of other research findings which the thesis has established throughout the various phases of the research. These are discussed in the following subsections of this chapter. 


\subsection{PART II: CONCEPTUAL FRAMEWORK}

Since all research questions employ concepts which are alien to positive EU VAT law (e.g. tax information, asymmetry), the thesis required a conceptual framework. Following the introduction (Part I), Part II of the thesis provided, partly on the basis of the information sciences, the necessary concepts and their definitions. The thesis defined tax information as information which is necessary for the design, implementation, application, administration, supervision, and enforcement of a tax. In the context of the thesis, tax information consists of information related to the actual object and subject of taxation, which is required for the application and administration of the tax by the taxable person. A tax information asymmetry is defined as a situation in which one party has (or can access) tax information that another party does not have (or cannot access) but which is required by the latter, possibly in a specific form, in the course of taxation.

\subsection{PART III: LEGAL FRAMEWORK}

Part III explored the legal origin of horizontal tax information asymmetries between the taxable person and his transaction counterpart in the specific context of EU VAT. The reason for this research process is that all four research questions of the thesis employ the legal position of the taxable person as the perspective from which the phenomenon of asymmetries is approached and ultimately researched. This demands insight into the manner in which the norms applicable to the taxable person may lead to the situation that he finds himself in need of external tax information.

The thesis has approached the legal origin of horizontal tax information asymmetries with regard to the legal nature of VAT and the legal norms of positive EU VAT law. As regards the legal nature of EU VAT, the phenomenon of horizontal tax information asymmetries can be explained partly by the circumstance that the EU VAT system employs the taxable person as a vehicle to impose a VAT burden on another person (i.e. the final consumer). Another explanatory factor is the circumstance that EU VAT aims to burden consumption by taxing transactions, yet both consumption and transactions are, at least to some extent, external phenomena from the perspective of the taxable person who is held to apply and substantiate VAT. Both aspects of the legal nature of EU VAT presuppose, at least to a certain extent, horizontal tax information procurement by the taxable person.

With regard to the norms of positive EU VAT law, the thesis concludes that the legal origin of horizontal tax information asymmetries is founded on three categories of rules: the substantive norms of taxation, the administration and dis- 
close rules and sanctions. The combination of these three elements is the reason that the horizontal exchange of tax information between the taxable person and his transaction counterpart is an indispensable element of taxation. The substantive norms necessitate the horizontal procurement of tax information for the application of VAT by the taxable person. Conversely, the administration and disclosure rules necessitate the horizontal procurement of tax information for the substantiation of VAT by the taxable person vis-à-vis the national public authorities, possibly with a prescribed form and content. Sanctions attach commitment to the application and substantiation of VAT by the taxable person and thus also to the horizontal procurement of tax information.

With reference to the above, the thesis concludes that the horizontal procurement of tax information by the taxable person is an indispensable part of the current EU VAT system.

\subsection{PART IV: THE LEGAL IMPLICATIONS OF HORIZONTAL TAX INFORMATION ASYMMETRIES}

The purpose of Part IV of the thesis was to address the research questions to what extent horizontal tax information asymmetries have legal implications for the taxable person and to what extent they should have legal implications for the taxable person. This section discusses both research questions separately.

Research question I: To what extent do horizontal tax information asymmetries in the field of EU VAT have legal implications for the taxable person?

The rationale underlying the above research question is that horizontal tax information asymmetries are not academically or practically relevant if the taxable person will not face any legal implications following their occurrence. Firstly, the research question demands insight into the categories of legal implications that may follow from an asymmetry. As a general implication, the thesis concludes that the materialization of an asymmetry causes the taxable person not to apply and substantiate VAT in line with the objective characteristics of the underlying transaction and the legal requirements. Following this, the national public authorities may impose two types of legal implications: material VAT corrections and sanctions. Material VAT corrections are imposed if the asymmetry leads the taxable person to apply VAT contrary to the objective characteristics of the transaction or if it leaves him unable to substantiate his application of VAT. Sanctions are imposed to penalize fiscal conduct when the asymmetry has caused it to be in violation of the legal requirements. 
As a second aspect, the above research question demands insight into the extent to which the taxable person faces the legal implications associated with the materialization of an asymmetry. The thesis has established that, as a general rule, the legal implications associated with the materialization of a horizontal tax information asymmetry (i.e. material VAT corrections, sanctions) are imposed on the taxable person who, because of the asymmetry, is unable to apply and substantiate VAT in line with the legal requirements and the objective characteristics of the underlying transaction. CJEU case law validates the conclusion that it is the taxable person acting as the subject of taxation who in first instance bears the material burden of VAT in case an asymmetry frustrates the process of taxation; moreover, he may also be sanctioned for it. ${ }^{1}$ Following this, the distribution of the legal implications can be said to be one-sided: generally, neither the transaction counterpart nor the national public authorities face any legal implications (i.e. the material burden of VAT, sanctions) in case a horizontal tax information asymmetry arises.

There are some nuances to the general rule that the legal implications of asymmetries are concentrated at the level of the taxable person. Firstly, in a limited number of situations, the CJEU has provided judgments in which legal implications (material VAT corrections) were averted for the taxable person - meaning that the national public authorities were required to forfeit their VAT claims. ${ }^{2}$ In two instances (i.e. Euro Tyre, Teleos and others) the CJEU even ruled that, instead of the taxable person, the transaction counterpart should be confronted with the material burden of VAT. ${ }^{3}$ Another nuance is that the taxable person, in a limited number of situations, may be able to influence the occurrence and distribution of legal implications by charging VAT against the standard VAT rate, irrespective of the objective characteristics of the underlying transaction. Notwithstanding this, charging VAT is not an effective instrument to avoid the legal implications associated with a horizontal tax information asymmetry in case a) the transaction counterpart (customer) does not pay the charged VAT to the taxable person effecting the supply, or b) the taxable person effecting the supply is unaware of being subject to an asymmetry, or c) the asymmetry relates to a determinant for the place of supply or the right of

\footnotetext{
${ }^{1}$ In numerous CJEU cases, the national public authorities initially impose legal implications on the taxable person who is subject to an asymmetry, e.g. CJEU, 23 April 2015, C-111/14, GST - Sarviz Germania, ECLI:EU:C:2015:267; CJEU, 9 October 2014, C-492/13, Traum, ECLI:EU:C:2014:2267; CJEU, 16 December 2010, C-430/09, Euro Tyre Holding, [2010] ECR I-13335; CJEU, 21 February 2008, C-271/06, Netto Supermarkt, [2008] ECR I-771; CJEU, 27 September 2007, C-409/04, Teleos and others, [2007] ECR I-7797; CJEU, 27 September 2007, C-184/05, Twoh International, [2007] ECR I7897.

2 E.g. CJEU, 23 April 2015, C-111/14, GST - Sarviz Germania, ECLI:EU:C:2015:267; CJEU, 9 October 2014, C-492/13, Traum, ECLI:EU:C:2014:2267; CJEU, 21 February 2008, C-271/06, Netto Supermarkt, [2008] ECR I-771; CJEU, 27 September 2007, C-409/04, Teleos and others, [2007] ECR I-7797. 3 CJEU, 16 December 2010, C-430/09, Euro Tyre Holding, [2010] ECR I-13335; CJEU, 27 September 2007, C-409/04, Teleos and others, [2007] ECR I-7797.
} 
deduction. As an instrument for avoiding the legal implications of asymmetries, the charging of (undue) VAT can thus be said to be imperfect.

Thirdly, the general implication that an asymmetry leads the taxable person to misapply and missubstantiate VAT also uncovers the erosive effect of asymmetries on the proper functioning of the VAT system. The thesis has established that horizontal tax information asymmetries may imply a differential VAT treatment of similar transactions, adverse selection, accumulation of VAT, conflicts with the ratio legis of substantive norms, and non-taxation and double taxation. Even though these phenomena on their own account do not constitute legal implications for the taxable person, they are relevant as they frustrate the neutral application of VAT. Further, as regards the missubstantiation of VAT, horizontal tax information asymmetries lead to an incorrect, incomplete or even non-existent administrative reflection of taxation - thus frustrating the public functions of supervision and enforcement. The circumstance that the above phenomena constitute adversities with regard to the principles underlying EU VAT simultaneously makes them arguments in support of legal remedies which carry the potential of countering the materialization of horizontal tax information asymmetries. The mentioned adversities validate the conclusion that horizontal tax information asymmetries should be countered in any justifiable way possible. ${ }^{4}$

The conclusion that the legal implications of asymmetries are generally concentrated at the level of the taxable person logically leads one to the question whether the imposition of legal implications is justified. The rationale of this question is that asymmetries are only academically relevant to the extent that the associated legal implications imposed on the taxable person cannot be justified on the basis of the norms applicable in EU VAT. Thus, to this end, the thesis has addressed the following research question:

Research question II: To what extent should horizontal information asymmetries have legal implications for the taxable person with regard to the neutrality principle, the principle of legal certainty, the principle of legal simplicity and effectiveness, and the principle of proportionality?

In the context of the second research question, the thesis has established that four legal principles are recurrently present in CJEU case law and, as such, function as the normative foundation for answering the above research question: the principle of fiscal neutrality, the principle of legal certainty, the principle of legal simplicity and effectiveness, and the principle of proportionality.

\footnotetext{
${ }^{4}$ Chapter 20 contains various recommendations as regards the countering of horizontal tax information asymmetries.
} 
The thesis has produced the conclusion that the imposition of legal implications associated with horizontal tax information asymmetry should depend on a weighing of the various legal principles against the backdrop of the particular case facts at hand. This means not only that each situation is to be judged on its own characteristics but also that the legal principles are relative, in the sense that their influence on the extent of legal implications is the product of a process of balanced weighing. Different circumstances as well as different principles may support a different outcome. For example, the principle of fiscal neutrality demands the imposition of material VAT corrections in case a taxable person, because of an asymmetry involving incorrect tax information, has applied an exemption contrary to the objective characteristics of the transaction. However, the principle of fiscal neutrality may very well be superseded by the legitimate expectations of the taxable person (i.e. as an expression of the principle of legal certainty) even when the national public authorities have initially accepted the authenticity of the incorrect tax information. In that situation, the weighing of the principles may lead to an outcome where legal certainty is given precedence - following which the asymmetry should not have any legal implications (i.e. material VAT corrections) for the taxable person. With regard to their relativity, the thesis has referred to the legal principles as vectors. The conclusions of the thesis are discussed below, separately for each of the mentioned principles.

\section{Ad 1: The principle of fiscal neutrality}

As regards the principle of fiscal neutrality, the thesis concludes the following. In its legal dimension, the principle demands that transactions are taxed according to their objective characteristics. The reason is that similar goods and services, which are thus in competition, are not to be treated differently for VAT purposes. Following this, asymmetries should not have legal implications (i.e. material VAT corrections) for the taxable person in case their imposition would lead to an application of VAT not in line with the objective characteristics of the transaction. This is for example the case when the national public authorities deny an application of the exemption for an intra-Community supply of goods when the substantive requirements for that exemption have been met, solely on the basis of the fact that the supplier is subject to an asymmetry as regards the VAT identification number of his customer. In this context, the principle of fiscal neutrality demands that asymmetries should not have legal implications (i.e. material VAT corrections) in case these asymmetries lead to infringements of a mere formal nature without taking into account the objective characteristics of the transaction. In the example above, the national public authorities should forfeit their VAT claims.

Conversely, the principle constitutes a vector which supports the imposition of material VAT corrections on the taxable person in case that would have the result 
of an application of VAT in line with the objective characteristics of the transaction. For example, where the taxable person is subject to an asymmetry as regards the fact that the actual transport destination of the goods he supplied is within the same Member State, the principle of fiscal neutrality, by demanding the same VAT treatment of similar and competing goods, supports the imposition of material VAT correction when the taxable person has applied the exemption for intraCommunity supplies of goods. Thus, with a specific view to the legal dimension of the principle of fiscal neutrality, the extent to which an asymmetry should have legal implications for the taxable person depends on whether such legal implications (i.e. material VAT corrections) carry the potential of achieving taxation in line with the objective characteristics of the transaction.

The principle of fiscal neutrality in its legal dimension also exerts its influence when a horizontal tax information asymmetry is ultimately resolved. In that situation, the principle as a vector demands that the taxable person is allowed to make amendments to his initial application of VAT, without running the risk that the national public authorities deny these amendments. For example, the principle of fiscal neutrality is a vector which demands that transaction counterparts enjoy the opportunity of correcting VAT which was charged unduly by the taxable person. In this regard, the principle bestows a certain flexibility on the system of VAT - as it may allow a taxable person to use the ultimately disclosed tax information in order to bring the application of VAT in line with the objective characteristics of the transaction. In such instances, the asymmetry thus ultimately should not have any legal implications for the taxable person (i.e. in the form of a denial of the amendments by the national public authorities) in case the late tax information allows for the application and substantiation of VAT in line with the objective characteristics of the underlying transaction. This is only different when precedence is to be given to other vectors; for example, in case reasonable time limits have been exceeded, the principle of legal certainty may justify a denial of amendments by the taxable person.

Notwithstanding the above, the principle of fiscal neutrality also has an economic dimension - which supposes that the levy of VAT is proportional to the price of the respective good or service. Taking this dimension into account, the thesis concludes that the principle of fiscal neutrality is a vector which opposes legal implications (i.e. material VAT corrections) for the taxable person in case he is unable to transfer the burden of VAT to his transaction counterpart further down the supply chain. In case material VAT corrections cannot be imposed on those persons on whom the final burden of VAT should indeed rest, the national public authorities should forfeit their VAT claims. Nonetheless, if the transaction counterpart is a final consumer, and the taxable person effecting the supply is unable to transfer the burden of VAT to that person, the principle in my view supports, at least theoretically, the imposition of a material VAT correction on the 
final consumer, as it would achieve a proportional levy of VAT without burdening any taxable person within the supply chain. ${ }^{5}$ Such a situation may for example materialize when, in the context of a B2C telecommunications service, the taxable person was not able to establish the place of residence of the final consumer due to an asymmetry. Finally, the economic dimension of the principle of fiscal neutrality also relates to the area of sanctions. In a situation in which an asymmetry prevents the taxable person from applying and substantiating VAT in line with the legal requirements, the principle opposes the imposition of a sanction (fine) which essentially constitutes a double levy of VAT, as that violates the proportional levy of VAT.

Finally, the principle of fiscal neutrality constitutes a vector of relevance when looking at situations involving asymmetries experienced by the taxable person in his capacity as a customer in a transaction. In order to safeguard the neutrality of taxation and the proportional levy of VAT, the right of deduction can in principle not be limited. Thus, invoices which are issued late should not obstruct the exercise of the right of deduction. Similarly, in case of an incorrect invoice, the principle of fiscal neutrality (in combination with the principle of proportionality) demands that the gravity of the infringement and the risk of loss of tax revenues for the national public authorities are taken into account when establishing the legality of legal implications (i.e. a denial of deduction); parties should be provided with the possibility of correcting the respective invoice. As regards the right of deduction, the above validates the conclusion that it is first and foremost a right bestowed on the taxable person acting as a customer and not a conditional allowance which the national public authorities may deny at their own discretion whenever the transaction counterpart (i.e. supplier) has failed to meet his legal obligations in the course of taxation. In simple terms, the primary purpose of deduction is to ensure the neutral and proportional levy of VAT, not to serve (in the form of a denial of deduction) as a sanctioning instrument that safeguards the budgetary interests of the national public authorities. Further to this, the denial of deduction may not be used to compel the taxable person acting as a customer to take on responsibilities which are inherent in the public function of supervision and enforcement.

\section{Ad 2: The principle of legal certainty}

The principle of legal certainty demands that a legal system and its application should be clear and precise, so that individuals may ascertain unequivocally what their rights and obligations are and may take steps accordingly. The thesis concludes that the principle exerts influence on the extent of legal implications in situ-

\footnotetext{
5 Imposing material VAT corrections on final consumers would however constitute a practically complex affair; it thus displays an uneasy relation with the principle of legal simplicity and effectiveness.
} 
ations in which the taxable person intends to make amendments to his initial application of VAT - e.g. when the horizontal tax information asymmetry is ultimately resolved by the disclosure of the necessary tax information. Even though the principle of fiscal neutrality is a vector which supports the possibility of amendments as they ultimately allow VAT to be applied in line with the objective characteristics of the transaction - the principle of legal certainty can have a directly opposing effect. CJEU case law underlines that the application of VAT without any temporal limit would be contrary to the principle of legal certainty, as the latter requires the tax position of the taxable person not to be open to challenge indefinitely. In other words, the taxable person should make amendments within a reasonable time frame or otherwise be exposed to the risk that they are denied by the national public authorities. With regard to this, the thesis concludes that a horizontal tax information asymmetry can and should have legal implications for the taxable person (e.g. in the form of the denial of amendments) in case he is unable to resolve it within a reasonable time frame. This underlines the relevance of (timely) access to external tax information.

The corollary of the principle of legal certainty is the principle of legitimate expectations. The latter principle requires that when the conduct of the authorities gave rise to a reasonable expectation in the mind of a reasonably prudent economic agent, the legitimate nature of that expectation must be respected. The thesis concludes that the principle of legitimate expectations (as an expression of the principle of legal certainty) constitutes a vector which provides that horizontal tax information asymmetries should not have legal implications (i.e. material VAT corrections) for the taxable person in case that person, while being subject to an asymmetry, has relied on legitimate expectations in the course of taxation. This is for example the case when the national public authorities initially have accepted the tax information (i.e. documentary evidence) used by the taxable person as legitimate, while in fact it did not represent the objective characteristics of the underlying transaction. In such instances, the principle of legal certainty (legitimate expectations) may take precedence over the legal dimension of the principle of fiscal neutrality (which demands the application of VAT in line with the objective characteristics of VAT) and prohibit the imposition of legal implications on the taxable person. If so, the national public authorities should forfeit their VAT claims, to the detriment of their own budgetary position.

\section{Ad 3: The principle of legal simplicity and effectiveness}

The principle of legal simplicity and effectiveness provides that, as a practical necessity, the system of VAT operates effectively. The application of VAT should thus be as simple and uncomplicated as possible; obligations must not, by reason of their number or technical nature, render the application and substantiation of 
VAT practically impossible or excessively difficult. By virtue of its nature, the principle of legal simplicity and effectiveness predominantly exerts influence on the legality of (national) tax information requirements imposed on the taxable person. In this context, the thesis concludes that asymmetries should not have legal implications for the taxable person in case the asymmetries are effectively the consequence of obligations which have, to an unreasonable extent, complicated the application and substantiation of VAT by the taxable person. In connection with the right of deduction for example, it is unreasonable to require that the taxable person, in his capacity as a customer, verifies the VAT status of his transaction counterpart (i.e. supplier) and ascertains that the latter has met his obligations as regards the declaration and payment of VAT. Such a requirement - which by its very nature belongs to the public function of supervision and enforcement - makes it practically impossible, or at least excessively difficult, to exercise the right of deduction because it is likely to imply a horizontal tax information asymmetry for the taxable person. In such situations, the principle of legal simplicity and effectiveness is a vector which opposes the respective (national) tax information requirement and thus also the legal implications (e.g. a denial of deduction, sanctions) which are imposed on the taxable person who is unable to comply.

\section{Ad 4: The principle of proportionality}

The principle of proportionality demands that measures must not go beyond what is necessary to attain the objective of ensuring the correct collection of the tax; they should be appropriate for the legitimate objective that they serve. The thesis has illustrated that the principle expresses standards of reasonability, also in connection with the conduct of the taxable person and his transaction counterpart.

Firstly, the thesis concludes that the principle of proportionality demands that asymmetries should not have legal implications (i.e. material VAT corrections) for the taxable person in case the asymmetries lead to a mere formal infringement, while the material conditions of taxation have been met. In this regard, the principle of proportionality is a vector which opposes an unreasonably strict and formalistic approach to taxation. When the principle is to be given precedence, the national public authorities should forfeit their VAT claims. This is only different when non-compliance with the formality effectively prevents the taxable person from establishing that VAT has been applied in line with the objective characteristics of the transaction.

Another conclusion of the thesis is that the principle of proportionality demands the weighing of the conduct of the taxable person and his transaction counterpart in the course of taxation. There are two primary elements in this regard: the good faith of parties and the efforts which they have exerted to resolve the horizontal tax information asymmetry or prevent its materialization. In case a taxable 
person has acted in good faith and has done everything which could reasonably be expected from him to resolve the asymmetry or prevent its materialization, the principle of proportionality is a vector which opposes the imposition of legal implications (i.e. material VAT corrections and sanctions) on that person.

As regards good faith, the thesis concludes that not acting in good faith (i.e. acting in bad faith) is only a relevant factor to be weighed in connection with the legal implications of asymmetries in case the national public authorities are exposed to the risk of loss of tax revenues. Even though it may lead to calculative behavior on the side of the taxable person (i.e. taxable persons may purposefully misclassify transactions in case there is no risk of loss of tax revenues), the thesis concludes that the CJEU doctrine on this point is justified with regard to the circumstance that the national public authorities would otherwise be able to unduly enrich themselves at the expense of the taxable person.

As regards the exerted efforts, the thesis concludes that the taxable person is subject to an investigative responsibility in the course of taxation, which is a measure of the effort he can reasonably be expected to exert in order to procure external tax information in support of the application and substantiation of VAT. In case the taxable person has done everything which could reasonably be expected from him to resolve the asymmetry or prevent its materialization, the principle of proportionality constitutes a vector which demands that he should not be confronted with the imposition of legal implications (i.e. material VAT corrections, sanctions). The boundaries of the investigative responsibility are by no means fixed; they depend on the relevant circumstances at hand which are weighed on grounds of reasonability. Signals which are suggestive of different or changed case facts generally expand the investigative responsibility of the taxable person; upon their receipt, he should exert additional efforts to refute or confirm these signals. Further, the investigative responsibility of the taxable person is limited in case the taxable person is fully incapacitated as regards the (horizontal) procurement of tax information - e.g. when the tax information has been lost following a natural disaster. Additionally, the thesis concludes that the investigative responsibility of the taxable person does not go as far as to effectively constitute a transfer of the supervision and enforcement responsibilities of the national public authorities to the taxable person.

In sum, the principle of proportionality opposes the imposition of legal implications (i.e. material VAT corrections, sanctions) on the taxable person and his transaction counterpart in case they have acted in good faith and have done everything which could reasonably be expected from them to resolve the asymmetry or prevent its materialization. If both have acted in good faith and have done everything which could reasonably be expected from them, the principle of proportionality is a vector which demands that the national public authorities should not im- 
pose sanctions and should forfeit VAT claims to the detriment of their own budgetary position (e.g. when accounts are lost following a natural disaster). Alternately, if either the taxable person or his transaction counterpart has not acted in good faith and has not done everything which could reasonably expected from him to prevent or resolve the asymmetry (e.g. when he neglects to disclose tax information or when he intentionally discloses incorrect tax information), the principle is a vector which supports the imposition of legal implications (i.e. material VAT corrections, sanctions) on that party - as they would serve the legitimate purpose of the correct application of VAT. The potency of the principle of proportionality in this regard is underlined by the CJEU judgments in Teleos and others and Euro Tyre, where the Court denies the imposition of material VAT corrections on the taxable person who is subject to a horizontal tax information asymmetry and instead rules that the transaction counterpart should be held liable for VAT in case of a contract breach on the latter's part.

Focusing on the legal position of the taxable person, the thesis concludes that his good faith and his exerted efforts are to be regarded in conjunction with each other. Together, they reflect the attitude and conduct which is expected of the taxable person with regard to the legitimate interests of the treasury and the premise that VAT is to be applied and substantiated in line with the objective characteristics of the transaction and the legal requirements. The weighing of the conduct of the taxable person against the backdrop of the principle of proportionality is a central factor of influence when determining to what extent asymmetries should have legal implications for the taxable person. The reason for this is that it may shield the taxable person from the legal implications of asymmetries (i.e. material VAT corrections and sanctions) when he ultimately is not able to resolve the horizontal tax information asymmetry or prevent its materialization despite his good faith and exerted efforts. By means of its case law, the CJEU thus recognizes the possibility that there are circumstances beyond the control of the taxable person, for which he is not to be held accountable. For example, a transaction counterpart may categorically refuse to disclose tax information or may even mislead the taxable person with incorrect tax information or a contract breach. In such situations of unilateral dependency, the thesis concludes that the principle of proportionality is a vector which renders the imposition of legal implications on the taxable person disproportionate when the taxable person has acted in good faith and has done everything which could reasonably be expected from him to resolve the asymmetry or prevent its materialization. In this sense, the case law of the CJEU provides a valuable opportunity for taxable persons: if they are willing to act in good faith and exert reasonable efforts to achieve a correct application and substantiation of VAT, they can count on a certain extent of legal protection when the process of taxation is ultimately frustrated by horizontal tax information asymmetries. 
Further to the first research question, the thesis has concluded that the taxable person may influence the extent to which horizontal tax information asymmetries have legal implications, i.e. by charging VAT against the standard VAT rate irrespective of the objective characteristics of the underlying transaction. In this context, the thesis concludes that following the principle of proportionality, the charging of (undue) VAT by the taxable person should be allowed (and not be sanctioned) in case he has exploited, in all reasonability, all of the available alternative courses of action which would potentially have allowed him to resolve or prevent the asymmetry and to apply VAT in line with the legal requirements. In such situations, the taxable person may attempt to mitigate the risk of legal implications associated with the asymmetry (i.e. material VAT corrections and sanctions) by charging VAT.

The principle of proportionality also relates to the area of sanctions. In this context, the principle implies that they must serve the correct levy of VAT and should be graduated according to the gravity of the infringement. An asymmetry should therefore not imply a sanction in case the taxable person, because of the asymmetry, has misapplied or missubstantiated VAT where he has acted in good faith and has done everything which could reasonably be expected from him. In such instances, the imposition of a sanction does not promote the correct levy of VAT (and thus does not serve a legitimate purpose), simply because the taxable person, with or without a sanction, was unable to apply and substantiate VAT in line with the objective characteristics of the transaction and the applicable legal requirements. In contrast, in case a taxable person (or his transaction counterpart) has acted in bad faith or did not exert reasonable efforts to resolve or prevent the asymmetry, the principle of proportionality supports the imposition of sanctions on that person to promote the correct levy of VAT.

\subsection{PART V: TAX INFORMATION ASYMMETRIES IN CONNECTION WITH THE SUBSTANTIVE NORMS OF TAXATION}

Part $\mathrm{V}$ of the thesis has studied the substantive norms of taxation in connection with the tax information position of the taxable person. The substantive norms of taxation are the material legal norms and conditions which determine and prescribe the application of VAT.

As a first element, Part $\mathrm{V}$ of the thesis addressed the research question to what extent positive EU VAT law implies the risk of horizontal tax information asymmetries and any associated unjustified legal implications for the taxable person. The reason for this research question is that asymmetries and the associated legal 
implications are not academically or practically relevant if their occurrence is merely a hypothetical or marginal phenomenon with regard to positive EU VAT law.

Research question III: To what extent does positive EU VAT law imply the risk of horizontal tax information asymmetries and any associated unjustified legal implications for the taxable person?

As regards the above research question, the thesis concludes that the materialization of asymmetries is a real possibility - as evidenced by the sizeable body of CJEU case law which deals with frustrated access to external tax information. Especially the substantive norms underlying the place of supply and the exemptions contain elements which make the taxable person dependent on external tax information - and consequently expose him to the potential materialization of horizontal tax information asymmetries. These norms have in common that they rely on determinants for taxation which are exogenous to the taxable person: transport trajectories, locational determinants (e.g. the place of establishment of the customer), even the VAT treatment of transactions carried out by other taxable persons (closely linked or related supplies). ${ }^{6}$ In this context, the thesis further concludes that positive EU VAT law provides no adequate legal instruments (e.g. disclosure rules which compel transaction counterparts to disclose) or competences (e.g. the power to demand disclosure of tax information by transaction counterparts) on which the taxable person can rely to resolve or prevent asymmetries. This suggests that the taxable person is expected to arrange the procurement of external tax information on the basis of his commercial interaction with transaction counterparts (e.g. by means of contractual agreements).

Additionally, the third research question relates to the extent to which positive EU VAT law implies the risk of unjustified legal implications for the taxable person. Further to the first research question, the thesis has concluded that the legal implications of an asymmetry (i.e. material VAT corrections, sanctions) are generally imposed on the taxable person who, because of the asymmetry, is unable to apply and substantiate VAT in line with the objective characteristics of the underlying transaction and the legal requirements. In case an asymmetry relates to tax information in support of a mere formality (e.g. the requirement to produce a VAT identification number), CJEU case law in my view provides solid grounds to avert any unjustified legal implications of asymmetries (i.e. material VAT corrections). The reason is that with regard to formal infringements, the Court has repeatedly

\footnotetext{
${ }^{6}$ Conversely, substantive norms which relate to the internal organization of the taxable person himself (e.g. norms on the taxable person status), or norms which are commonly the product of the commercial conclusion of a transaction (e.g. the taxable amount), are less likely to cause horizontal tax information asymmetries.
} 
prohibited the imposition of material VAT corrections in case the substantive requirements of taxation had been met. ${ }^{7}$ Yet, where an asymmetry relates to tax information in support of material conditions of taxation, the CJEU up to now has only prohibited the imposition of legal implications in a limited number of judgments. These judgments (i.e. GST - Sarviz Germania, Traum, Euro Tyre, Netto Supermark.t, Teleos and others ${ }^{8}$ ) are relatively recent, implying that their legal effect on national legal orders is a rather novel phenomenon. In addition, these CJEU judgments predominantly relate to transactions which take place in an international context. In fact, with the exception of Netto Supermarkt, they concern intraCommunity B2B trade. Taking this into account, the Court's rulings should arguably be viewed merely in light of the ambition of promoting the internal market. As regards other sections of EU VAT law (e.g. the place of supply rules, exemptions without a right of deduction, reduced VAT rates), CJEU case law on the legal implications of asymmetries is lacking. The circumstance that the CJEU judgments on the legal implications of asymmetries are relatively few in number, relatively recent, and almost exclusively related to intra-Community trade, supports the position that their legal impact on national legal orders is currently still modest. Further to this, the thesis concludes that positive EU VAT law cannot with certainty be said to fully avert the risk of unjustified legal implications for the taxable person, especially not if the asymmetry concerns tax information in support of the material requirements of taxation. ${ }^{9}$

Part V has further addressed the research question to what extent legal remedies should, with regard to appropriate law, avert the materialization of asymmetries for the taxable person. In other words, this part of the thesis concentrates on the question whether statutory (EU) VAT law can and should be amended in such a manner as to reduce or avoid horizontal tax information asymmetries for the taxable person without eroding the current structural elements of the system of

\footnotetext{
7 E.g. CJEU, 20 October 2016, C-24/15, Plöckl, ECLI:EU:C:2016:791, paragraph 42; CJEU, 15 September 2016, C-518/14, Senatex, ECLI:EU:C:2016:691, paragraph 38; CJEU, 9 July 2015, C-183/14, Salomie and Oltean, ECLI:EU:C:2015:454, paragraph 58; CJEU, 11 December 2014, C-590/13, Idexx Laboratories Italia, ECLI:EU:C:2014:2429, paragraph 38; CJEU, 1 March 2012, C-280/10, Polski Trawertyn, ECLI:EU:C:2012:107, paragraph 43.

8 Respectively CJEU, 23 April 2015, C-111/14, GST - Sarviz Germania, ECLI:EU:C:2015:267; CJEU, 9 October 2014, C-492/13, Traum, ECLI:EU:C:2014:2267; CJEU, 16 December 2010, C-430/09, Euro Tyre Holding, [2010] ECR I-13335; CJEU, 21 February 2008, C-271/06, Netto Supermarkt, [2008] ECR I-771; CJEU, 27 September 2007, C-409/04, Teleos and others, [2007] ECR I-7797.

${ }^{9}$ I note that the materialization of horizontal tax information asymmetries and their legal implications ultimately depends, at least partly, on national law and the manner in which national judiciary and public administration institutions carry out their tasks. Since exhaustive research on national legal orders was however excluded from the scope of the thesis (refer to section 1.6), I advocate for further research on (the legal implications of) horizontal tax information asymmetries on a national legal level - particularly in the fields of national VAT law and national administrative law. For further reading on this recommendation, refer to section 20.4.2.
} 
levying VAT. As such, the thesis thus approaches the phenomenon of asymmetries from the perspective of the $(\mathrm{EU})$ legislator, who functions as one of the primary addressees of the thesis.

Research question IV: If horizontal tax information asymmetries can have unjustified legal implications for the taxable person, and moreover are a real possibility, in what manner, if any, should legal remedies be used to avoid their materialization?

With regard to the above research question, the thesis firstly established that asymmetries cause the taxable person to apply and substantiate VAT contrary to the objective characteristics of the transaction and the legal requirements. This is connected with various adversities: double taxation, non-taxation, accumulation of VAT, adverse selection, differential VAT treatment of similar transactions, and conflicts with the ratio legis of provisions of statutory EU VAT law. The mentioned phenomena validate the conclusion that the materialization of horizontal tax information asymmetries should be countered in any justifiable way possible. Following this, the thesis has addressed four categories of legal measures which have the potential of remedying horizontal tax information asymmetries and thus preventing the associated adversities: presumptions, disclosure rules imposed on transaction counterparts, disclosure rules imposed on the national public authorities, and investigative competences bestowed on the taxable person.

Research into the above-mentioned legal remedies allows for the conclusion that there is no single remedy which holds the potential of perfectly averting horizontal tax information asymmetries in all situations. The structural tenets and legal norms of the EU VAT system simply require horizontal exchanges of tax information; a circumstance which, by definition, implies the risk of asymmetries. Nonetheless, the discussed legal measures do carry the potential of reducing the dependency of the taxable person on external tax information and on the willingness of others to disclose. As such, they should be considered whenever legal norms have the tendency to maneuver the taxable person into a complex tax information position. However, the adoption of presumptions, disclosure rules or even investigative competences should always be based on a balanced weighing of the tax information advantages for the taxable person, the associated administrative burdens, the principles and theoretical ambitions inherent in the system of EU VAT, and the protection of privacy and other rights of the transaction counterpart.

The thesis concludes that presumptions can facilitate the tax information position of the taxable person, as they may 'replace' norms which rely for their application on items of tax information which are difficult to procure. However, a downside is that presumptions may erode the principles and theoretical ambitions inherent in the system of EU VAT. Disclosure rules imposed on transaction coun- 
terparts can be effective instruments when such persons in practice indeed prove to have access to the tax information required by the taxable person. However, their adoption necessitates sufficient supervision and enforcement by the national public authorities, and they constitute an intensification of the administrative burden of the transaction counterpart. Further, the thesis has concluded that disclosure rules imposed on the national public authorities are less evident remedies. The primary reason for this is that the authorities generally do not have timely and efficient access to up-to-date tax information on transactions (which may materialize on short notice or even change over time). Finally, with regard to the potential abuse inherent in them, the instrument of investigative competences bestowed on the taxable person should be employed only with the greatest caution - as it holds the risk of abuse of powers.

Further to the third and fourth research questions above, the points below address specific conclusions which the thesis has reached for each of the seven categories of substantive norms which were addressed in Part V.

\section{Ad 1: Taxable person}

The thesis concludes that the substantive norms underlying the concept of taxable person do not imply significant possibilities for the materialization of horizontal tax information asymmetries for the taxable person applying and substantiating VAT. The primary reason is that the norms are strongly connected with the existential nature of the taxable person himself, as well as the internal dimension of the (economic) activities which he initiates. The possibility of asymmetries between members of a VAT group, or between the primary and fixed establishments of a taxable person, is likely to be mitigated because of the economic, organization and financial links between the mentioned entities. As regards public bodies, the Court has ruled that a taxable person who is in competition with a public body and alleges that that body is, in respect of the activities in which it engages as a public authority, treated as a non-taxable person for VAT purposes is entitled to rely on article 13 VAT Directive before the national court in order to exact equal treatment. The thesis concludes that national law should provide adequate (legal) instruments for the taxable person to procure tax information on the (economic) activities of the (potentially competing) public body.

\section{Ad 2: Taxable transactions}

The thesis concludes that, in connection with the taxable transactions, CJEU case law has provided for various substantive norms which in a general sense can be said to facilitate the tax information position of the taxable person. The conditions of reciprocal performance, stipulation and legal relationship provide a convenient foundation for horizontal exchanges of tax information between transaction counterparts. The fact that these substantive norms are conditions for the taxability of a 
transaction indirectly serves the tax information position of the taxable person, as he can rely on the communicative channels which are inherent in the legal relationship, stipulation and reciprocity for the procurement of external tax information.

A further conclusion is that the norms underlying the taxable transactions only imply the possibility of horizontal tax information asymmetries in a limited range of situations. The risk predominantly arises when the taxable person structures the transaction in such a manner that he externalizes elements which define the occurrence of a taxable transaction (e.g. principal-agent relations, consignment and calloff stock situations). In this context, a notable aspect is that the transfer of the right to dispose of tangible property as an owner can follow from the actions of a party (agent), rather than from the actions of the taxable person (principal) himself. In such situations, the taxable person who effects a taxable transaction for VAT purposes (principal) may possibly be subject to an asymmetry vis-à-vis the agent as regards the occurrence of the taxable event itself.

As regards the question to what extent legal remedies (i.e. presumptions, vertical or horizontal disclosure rules) should be employed to avoid or reduce asymmetries for the taxable person, the thesis concludes that such measures should be used restrictively in the context of the substantive norms underlying the concept of a taxable transaction. The reason is that asymmetries in the occurrence of taxable transactions can generally be properly averted within the commercial and contractual context of the taxable transactions themselves. Should parties want to avoid asymmetries, the shared contractual basis, which is usually inherent in outsourcing, consignment stock and other principal-agent relations, can be employed not only to arrange commercial affairs, but also the proper exchange of tax information between parties. In case he has delegated or outsourced aspects of the transaction (e.g. in principal-agent relations), the taxable person (principal) should aim to contractually arrange with the agent the exchange of tax information on the factual occurrence of a taxable transaction, which is often caused by the actions of the agent.

\section{Ad 3: Place of supply}

The primary conclusion in connection with the substantive norms on the place of supply is that many of them are based on determinants which are external to the organization of the taxable person effecting the supply. This underlines the potential materialization of horizontal tax information asymmetries. For example, the $\mathrm{B} 2 \mathrm{~B}$ main rule for the place of supply of services depends on, among others, the VAT status of the customer, the place of establishment of the customer and the potential allocation to a fixed establishment of the customer. The external nature of these determinants for the place of supply exposes the taxable person to a real possibility of horizontal tax information asymmetries, as well as the associated legal 
implications which follow from their materialization. The possibility of asymmetries is also considerable in relation to the substantive norms of 'taxable dealer' status (supplies of gas, etc.), the norm of 'importation' (supplies of goods transported from third countries), the norm of the VAT status of the customer (distance selling and the supplies of services in general), the norm of the 'place of residence' of the customer (various B2C services, relating to very specific details, e.g. 'personal and occupational ties'), and the norm of 'effective use and enjoyment' (various categories of services) or 'use of the service provided' by an establishment (allocation of B2B main rule services to primary or fixed establishments).

In a general sense, the thesis concludes that there is a positive relationship between the risk of asymmetries and the extent to which the place of supply rule approximates the actual place of consumption. The reason for this is that place of supply rules, which approximate the actual place of consumption, rely to a greater extent on external determinants for the place of supply. A contributing factor in this regard is that the substantive norms often rely on tax information which is not by default disclosed on the basis of the commercial conclusion of the underlying transaction. Such items of tax information (e.g. 'personal and occupational ties', 'use of the service') are exogenous to the commercial context of the transaction and require standalone tax information procurement by the taxable person. Another contributing factor is formed by potential (dis)incentives at the level of the transaction counterpart. For example, a customer who is aware of the fact that his disclosure of tax information leads the taxable person to apply VAT in a certain country with a relatively high VAT rate may decide not to disclose at all (or to disclose incorrect tax information). In the context of (dis)incentives for disclosure, the thesis further underlines that the substantive norms on the place of supply contain various determinants which rely on tax information of a potentially private or confidential nature. Examples are the place where a non-taxable natural person has his permanent address or usually resides, the location and manner of use or consumption, and the place where the essential decisions concerning the general management of the business are taken. Motivations of privacy and confidentiality erode the likeliness that transaction counterparts engage in the horizontal disclosure of tax information. Such circumstances contribute to the materialization of asymmetries.

As regards the question to what extent legal remedies (i.e. presumptions, vertical or horizontal disclosure rules) should be employed to avoid or reduce asymmetries for the taxable person, the thesis concludes that such measures should predominantly rely on either presumptions or horizontal disclosure rules. Vertical disclosure rules, which require the disclosure of tax information to the taxable person by the national public authorities, are only appropriate when the respective tax information is available to the latter (e.g. tax information on the VAT status or 
place of residence of the customer, if he is a taxable person established in the EU). Such rules would however imply a burden for the national public authorities and potentially consume public resources which could be employed in a more productive manner. A more suitable legal remedy is provided by horizontal disclosure rules, which would oblige the transaction counterparts to disclose the tax information required by the taxable person. However, in case the counterpart is not established or residing in the EU, and in case he is a final consumer, the supervision and enforcement of such rules would be a legally complex and impractical affair. In this context, the thesis primarily supports the notion that the EU legislator should consider presumptions as a legal remedy, as they have the potential of relieving the tax information position of the taxable person without being subject to the disadvantages associated with vertical and horizontal disclosure rules. For example, in connection with the allocation of B2B main rule services to either the primary or a fixed establishment, asymmetries as regards the 'use' of the service can be avoided by adopting the presumption that the services are deemed to be provided to the establishment with which the contractual agreements have been concluded - possibly coupled with the opportunity to rebut. In relation to the VAT status of the customer for distance sales, another example is to adopt the presumption that the customer is deemed to be a final consumer (non-taxable person) acting as such, unless the latter provides a statement (e.g. via the webshop platform, including sufficient supporting tax information) to the contrary. In this regard, I note that the VAT Regulation already contains numerous presumptions which are specifically aimed at facilitating the tax information position of the taxable person; even the reliance on the VAT identification number for the VAT status and capacity of the customer can effectively be regarded as a presumption for these aspects. To the extent that legal remedies are not appropriate to avert the materialization of asymmetries, the taxable person should aim to arrange the exchange of the required items of tax information (for example, on the 'use' of a service by a fixed establishment) in the commercial context of the transaction (e.g. by specific clauses in the contracts).

\section{Ad 4: Taxable amount}

As regards the substantive norms underlying the taxable amount, the thesis concludes that they display a strong connection with information which is inherent in the commercial context in which transactions materialize. The circumstance that the stipulation of the taxable amount is commonly at the center of the mutual commercial interactions between transaction counterparts, justifies the general conclusion that horizontal tax information dependencies as regards the taxable amount are not often significant and that asymmetries are not likely to materialize. This is only different when the connections between the reciprocal performances 
are redirected by means of the intervention of a third party (e.g. third party factoring or payment processing and third party payments). Yet, even in such situations, the commercial relationship between the taxable person, who is held to apply and substantiate VAT (principal) and the third party (agent), allows for measures which reduce or eliminate the materialization of asymmetries (e.g. by contractual arrangements for the exchange of tax information). Since asymmetries in connection with the taxable amount are not likely to materialize, the thesis did not elaborate on the potential of legal remedies.

\section{Ad 5: Reduced $V A T$ rates and exemptions}

As regards reduced VAT rates, the thesis concludes that the taxable person effecting the supply may be subject to the possibility of asymmetries in particular when he needs to establish the actual use of the good or service by the customer in order to determine whether that use is in conformity with the use as required by one of the items listed in Annex III to the VAT Directive. Further to the question in what manner legal remedies should be used to avoid the materialization of asymmetries, the thesis concludes that horizontal disclosure rules imposed on transaction counterparts are not a suitable instrument, as the latter may very well be final consumers - which complicates the supervision and enforcement of such rules. Instead, the $(\mathrm{EU})$ legislator could consider, for certain specified products which have dual uses (e.g. horses or anti decubitus matrasses), adopting the presumption that the respective commodity is not used for the purpose mentioned in Annex III of the VAT Directive unless the transaction counterpart provides the taxable person effecting the supply with sufficient evidence supporting the opposite. This presumption would motivate transaction counterparts with a limited or no right of deduction to disclose the required tax information to the taxable person. However, it would not have such an effect when the transaction counterpart has a full right of deduction. Another disadvantage of such a presumption is that it would simultaneously require a specification of the items of proof (e.g. copies of slaughter licenses or medical affidavits), which would complicate the process of taxation and lead to an administrative burden for the transaction participants (including the taxable person). The unsuitability of the mentioned legal remedies advocates a revision of the interpretation of the substantive norms themselves, so that the taxable person effecting the supply is no longer held to establish for each commodity whether the actual use is in line with the use as required by Annex III of the VAT Directive.

As regards the exemptions, the thesis concludes that various substantive norms in connection with exemptions relate to affairs which are largely external to the taxable person effecting the supply, which thus holds the possibility of horizontal tax information asymmetries. In particular, the thesis has identified the following norms: 
- Close links or relations: Various exemptions extend their scope to closely linked activities or closely related activities. Such substantive norms can have considerable implications for the tax information position of the taxable person. The primary reason is that the VAT treatment of the closely related supply essentially depends on that of the principal supply, holding the possibility of asymmetries for a taxable person carrying out only the former. The requirement following from CJEU case law that the closely related supply is 'essential' for the primary supply if it is to fall within the scope of the respective exemption, creates the need for that taxable person to establish the quality and specifics of the primary supply, possibly requiring very detailed tax information which may not be accessible. These dependencies are aggravated by the potential circumstance that the taxable person has no direct (legal or commercial) relationship with either the end customer or the taxable person carrying out the principal supply. In such situations, the possibilities for horizontal tax information procurement are limited.

- Transport of goods to certain locations: Statutory EU VAT law contains various exemptions which depend on whether goods are transported to a certain location (e.g. to another Member State or non-EU country). Following common commercial practice, a taxable person may decide to outsource the actual transport of the goods, or delegate it to a transaction counterpart elsewhere in the supply chain. By doing so, the taxable person who applies the exemption maneuvers himself into a position of horizontal tax information dependency vis-à-vis the person effecting the transport. Horizontal tax information dependencies especially arise in relation to multiple consecutive supplies involving only one incidence of transport. In such situations, the (cross-border) transport needs to be allocated to one of the supplies. In Euro Tyre, the Court attaches significant weight to the location where the transfer of the right to dispose of the goods passes from one transaction participant to the other. In case both transfers take place in the Member State of origin, the first supply constitutes a local supply of goods. Similarly, the second supply is a local supply in case both transfers take place in the Member State of destination. In a three-party supply chain, the importance of the location of the transfer compels the taxable person, in simplified terms, to obtain tax information on 1) the occurrence of both transfers, on 2) the moment at which both transfers take place, and on 3) the location of the goods at the moment both transfers take place. The possibility of asymmetries in this regard comes down to the notion that, in situations involving a supply chain with only one incidence of transport and multiple consecutive supplies, the VAT treatment of one supply within the supply chain cannot be ascertained without sufficient tax information on one or more of the other supplies. Because of the tax information interdependencies between the different suppliers, the allocation of transport demands a 
supply chain perspective rather than a transactional perspective. Other than leverage following from commercial interrelations, the taxable person has no (legal) means available to obtain access to external tax information as regards the specifics of supplies in other stages of the supply chain. This contributes to the materialization of horizontal tax information asymmetries.

Further to the question in what manner legal remedies should be used to avoid the materialization of asymmetries in the context of exemptions, the thesis concludes that it depends to a great degree on the respective substantive norm. In general, however, vertical disclosure rules to be imposed on the national public authorities are not an effective legal remedy whenever the respective tax information relates to specific transactions - simply for the reason that the authorities do not have timely, efficient or in-depth access to that tax information (e.g. the transport trajectory of goods). Similarly, horizontal disclosure rules are often not a suitable instrument, in particular not when the transaction counterpart to be burdened with them is commonly a final consumer or a transaction counterpart established outside the respective Member State. In such situations, the supervision and enforcement of such rules would be a legally and practically complex affair. Finally, the thesis concludes that presumptions are also often an unsuitable instrument for the countering of asymmetries in the context of exemptions. The primary reason is that the substantive norms (i.e. the cross-border transport, the allocation of the transport, the close links or relations) can hardly be captured in easily accessible items of tax information which can be relied upon as a presumption for the transport, its allocation or the close links or relations. The exception to this concerns the VAT status and capacity of the customer in relation to the exemption for intra-Community supplies of goods: the EU legislator could consider adopting a presumption which allows the taxable person to rely on the nature of the goods supplied as a presumption for both the VAT status and capacity of the customer (e.g. when very large quantities of (consumer) goods are supplied). To the extent that legal remedies are not appropriate to avert the materialization of asymmetries, the taxable person should aim to arrange the exchange of the required items of tax information in the commercial context of the transaction (e.g. by specific clauses in the contracts).

\section{Ad 6: Chargeable event, chargeability, liability}

The thesis concludes that the substantive norms underlying the concepts of chargeable event and chargeability do not imply significant possibilities for the materialization of horizontal tax information asymmetries. The primary reason for this is that both aspects in first instance depend on the occurrence of a taxable transaction - an event on which transaction counterparts are commonly informed (save for exceptional situations involving consignment stocks or principal-agent 
relations). Also, the exceptions to the main rule of the moment of chargeability (i.e. payments on account, issue of the invoice, payment receipt) have no particular implications for the tax information position of the taxable person. With regard to this, the thesis did not need to address the question in what manner legal remedies should be employed to avert the possibility of asymmetries.

As regards the VAT liability, the thesis concludes that, in particular, the reverse charge mechanism is relevant. The reason is that it implies a redistribution of the tax information dependencies between the taxable person acting as a supplier and the taxable person acting as a customer. In a general sense, the tax information needs of the taxable person acting as a customer are intensified. However, in the context of the reverse charge mechanism, the thesis concludes that the possibility of horizontal tax information asymmetries is limited - in particular because both the supplier and customer have a shared interest in the correct application and substantiation of VAT. This shared interest constitutes an incentive for the horizontal exchange of tax information; asymmetries can be averted by means of arrangements within the commercial context of the respective transaction (e.g. contractual agreements on the exchange of tax information). Reviewing these aspects, the thesis did not need to address the question in what manner legal remedies should be used to counter the materialization of asymmetries.

\section{Ad 7: The right of deduction}

With regard to the right of deduction, the primary conclusion of the thesis is that the underlying substantive norms do not imply many significant possibilities for the materialization of horizontal tax information asymmetries for the taxable person acting in his capacity as a customer. The condition that supplies are made by a taxable person has only a few tax information implications for the taxable person acting as a customer - primarily because CJEU case law has restricted the extent to which national public authorities can demand the taxable person acting as a customer to procure tax information on the identity and VAT status of the supplier. Similarly, the condition of 'use for purposes for which a right of deduction exists' depends on the internal affairs of the taxable person and therefore is not likely to lead to the materialization of horizontal tax information asymmetries. Instead, the risk of asymmetries for the taxable person in his capacity as a customer primarily centers on the procurement of tax information that allows him to establish whether VAT was charged correctly (i.e. in line with the objective characteristics of the transaction), as unduly charged VAT is in principle not deductible. In case he wants to rely on the legality of his deduction, the taxable person should do everything which can reasonably be required from him to establish that VAT was indeed charged in line with the legal requirements and the objective characteristics of the underlying transaction. The thesis concludes that presumptions and vertical or 
horizontal tax information disclosure rules are not suitable instruments to avert asymmetries in this regard. As the correct application of VAT is often (partly) dependent on the disclosures by the taxable person acting as a customer, both transaction participants should instead cooperate by mutually disclosing tax information in the commercial context of the transaction, with the purpose of achieving a VAT treatment in line with the objective characteristics of the transaction. This can be achieved by contractually agreeing on the horizontal exchange of tax information. 